\title{
Demonstrative experiments on the migration of radiocesium from buried soil contaminated by the accident at Fukushima Daiichi Nuclear Power Station ${ }^{\dagger}$
}

\author{
Tetsuji YAMAGUCHI*1 Taro SHIMADA*1 Makoto ISHIBASHI*2 ${ }^{* 1}$ Yosuke AKAGI*2 Mitsuru KUROSAWA*2 \\ Akiyoshi MATSUBARA*2 ${ }^{*}$ Yuki MATSUDA*3 Shigeyoshi SATO*4 $^{* 4}$
}

\begin{abstract}
福島第一原発事故で污染された土袞を穴に埋設し，清浄な土壤で覆土寸れば，放射性セシウムは污染土壌から周りの 土壌や地下水にほとんど移行しないことは過去の研究から推定できる. 本研究では, 茨城県美浦村の 1 つの公園と埼玉 県三郷市の $2 つ の$ 公園において一年にわたって核種移行試験を行って，その推定を実証した。污染された表層土壌を集 めて埋設し, 散水によって放射性セシウムの移行を加速した. ボーリングコアの切断分析結果や, 土壌水の分析結果か らは, 放射性セシウムの動きは見られなかった。 また, 実験室におけるカラム移行試験および収着試験によって, 放射 性セシウムが污染土䗙からほとんど溶出しないことや，たとえ溶出しても周囲の土壌に収着されてほとんど移行しない ことを示すデータを得た。試験は 1 年間で終了したが，移流拡散モデルによるシミュレーション解析を 100 年間につい て行ったところ, セシウム-137 はほとんど移行せずにその場で減衰することが示された.
\end{abstract}

Keywords: 福島第一原発事故, 污染土壤, 放射性セシウム, 移行, 埋設, 収着

It is predictable from previous studies that radiocesium hardly migrates into surrounding soils and groundwater from soils contaminated by the accident at Fukushima Daiichi Nuclear Power Station if they are buried and covered with clean local soils. This study demonstrated the prediction by performing in-situ migration experiments over a year in a public park in Miho, Ibaraki prefecture and in two public parks in Misato, Saitama prefecture. Contaminated surface soils were gathered and buried at a depth range of $0.3 \sim 1.0 \mathrm{~m}$ or at $0.3 \sim 1.3 \mathrm{~m}$ and covered with clean local soil layer of $0.3 \mathrm{~m}$, and were sprinkled with water to accelerate the radiocesium migration. Migration of radiocesium was not observed from radiometric analyses of boring cores and soil water samples. Laboratory column and sorption experiments revealed that the radiocesium hardly leaches out of the soil and even if it leaches out from the contaminated soil, radiocesium is sorbed on surrounding soils and hardly migrates through the soil layer. Simulation of Cs-137 migration for 100 years by an advection-diffusion model showed that Cs-137 migrates slightly and decays out in the contaminated soil.

Keywords: Fukushima Daiichi NPS accident, contaminated soil, radiocesium, migration, burial, sorption

\section{Introduction}

Ground surface was contaminated in Kanto and Tohoku regions by radiocesium released from the accident at Fukushima Daiichi Nuclear Power Station after the great earthquake in eastern Japan on March 11 in 2011. It is necessary to quickly reduce the effect of the contamination on human health and to living environments. On-site burial, to remove the contaminated surface soils from schoolyards and parks, to accumulate them on site in a trench and to backfill the trench with clean local soils is a candidate for disposing measure of the contaminated soil. It is expected that removing the contaminated surface soils and burying them on site will decrease the dose rate on the ground surface. It is, however, necessary to ensure that radiocesium does

福島第一原発事故で污染された土壌の埋設場所からの放射性セシウムの移 行に関する実証試験 山口徹治(yamaguchi.tetsuji@jaea.go.jp), 島田太郎, 石 橋純, 赤木洋介, 黒沢満, 松原諒宜, 松田祐紀, 佐藤滋芳

* 1 Japan Atomic Energy Agency 日本原子力研究開発機構

2-4 Shirakata, Tokai, Ibaraki 319-1195, Japan

干319-1195 茨城県那珂郡東海村白方 2-4

*2 Mitsubishi Materials Corporation

三菱マテリアル株式会社

1-297 Kitabukuro, Omiya, Saitama, 330-8508, Japan

テ330-8508 さいたま市大宮区北袋町 1-297

*3 Mitsubishi Materials Techno Corporation

三菱マテリアルテクノ株式会社

1-297 Kitabukuro, Omiya, Saitama, 330-0835, Japan

テ330-0835 さいたま市大宮区北袋町 1-297

*4 Ministry of the Environment of Japan

環境省

1-2-2 Kasumigaseki, Chiyoda, Tokyo 100-8975, Japan

テ100-8975 東京都千代田区霞が関 1-2-2

$\dagger$ This project was conducted by Ministry of the Environment of Japan with technical support from Japan Atomic energy Agency and from Mitsubishi Materials Corporation.

(Received 16 January 2015; accepted 16 July 2015) not migrate from the contaminated soils buried on site.

Previous studies suggested that radiocesium exhibits low mobility because of sorption onto soils or sands. Kamiyama et al. (1994) [1] performed field tests on migration of H-3, Co-60, Cs-134 and Sr-85 over two years at the field site of loess layer in Shanxi, China and showed that most of the Cs-134 did not move. Sakamoto et al. (1999) [2] studied migration behavior of Sr-90 and Cs-137 in a sand aquifer at Chalk River Laboratories, Canada over 30 years and found that Cs-137 was fixed in the sand. Such demonstrations, however, have never been performed in Japan. In this study, demonstrative experiments on the migration of radiocesium from buried contaminated soil were performed at public parks in Kanto region, eastern Japan.

\section{Experimental}

\subsection{Field experiments}

Contaminated surface soil was gathered and buried in a public park A (site A) in Miho village, Ibaraki prefecture and in two public parks B and C (sites B and C) in Misato city, Saitama prefecture in March, 2013. Periodical boring of the soil cores and sampling of the soil water were performed for nearly 12 months to investigate the radiocesium migration.

\subsubsection{Site A in Miho village, Ibaraki prefecture}

A $3-\mathrm{cm}$ thick contaminated surface soil was stripped from relatively highly contaminated areas, $1200 \mathrm{~m}^{2}$, in the park. The surface soil was clayey fine sand (Table 1) with sparse vegetation. Mineralogical compositions were analyzed by XRD and shown in Table 2. Dose rate at $50 \mathrm{~cm}$ above the ground was typically $0.25 \mu \mathrm{Sv} / \mathrm{h}$ before the stripping and $0.13 \mu \mathrm{Sv} / \mathrm{h}$ 
afterwards, which suggested the effectiveness of this measure. A trench with an area of $6 \mathrm{~m} \times 6 \mathrm{~m}$ and a depth of $1.3 \mathrm{~m}$ was dug at an edge of the park as shown in Fig. 1. The dug soil was thoroughly mixed up and used in the field experiment as clean local soil. The contaminated soil with a volume of $36 \mathrm{~m}^{3}$ was buried in the trench at a depth range between 1.3 and $0.3 \mathrm{~m}$ and was covered with the clean local soils over $0.3 \mathrm{~m}$. The depth, 1.3 $\mathrm{m}$, was chosen considering the groundwater level and rationality of the construction. A $2 \mathrm{~m} \times 2 \mathrm{~m}$ area in the buried area was separated as an investigation area by a water impermeable steel frame over a depth of $1.8 \mathrm{~m}$. This investigation area was dug down to a depth of $1.8 \mathrm{~m}$ in advance to install a soil water collecting device and combination sensors (Hydra Probe II, SDI-12, Stevens Water Monitoring Systems, Inc., Portland, USA) at depths of 1.7, 1.4, 1.1, 0.8, 0.5 and $0.2 \mathrm{~m}$ to measure temperature, water content and electric conductivity. The setup of the field experiment is shown in Fig. 2.

The hydraulic conductivity had been between $3.5 \times 10^{-9}$ and $1.3 \times 10^{-7} \mathrm{~m} / \mathrm{s}$ before digging. Contaminated soil was buried in steps by repeating setting the soil with a thickness of $0.3 \mathrm{~m}$ or less and ramming mechanically or manually. After burying, a vertical boring was performed to identify the initial vertical distribution of radiocesium. Then, tap water was sprinkled over the investigation area to accelerate the radiocesium migration.

Table 1 Grain size distribution(wt\%) of the soils from the three depth ranges of the three sites.

\begin{tabular}{|c|c|c|c|c|c|c|}
\hline \multirow{2}{*}{$\begin{array}{c}\text { Grain size } \\
\text { Site and depth }\end{array}$} & $\begin{array}{c}\text { Clay } \\
(<5 \mu \mathrm{m})\end{array}$ & $\begin{array}{c}\text { Silt } \\
(5 \sim 75 \mu \mathrm{m})\end{array}$ & $\begin{array}{c}\text { Sand } \\
(75 \mu \mathrm{m} \sim 2 \mathrm{~mm})\end{array}$ & $\begin{array}{c}\text { Gravel } \\
(2 \sim 75 \mathrm{~mm})\end{array}$ & $\begin{array}{c}\text { Stone } \\
(75 \mathrm{~mm}<)\end{array}$ \\
\hline \multirow{3}{*}{ Site A A } & $0.2 \sim 0.4(\mathrm{~m})$ & 25.9 & 12.7 & 60.5 & 1.0 & 0.1 \\
\cline { 2 - 7 } & $1.2 \sim 1.4(\mathrm{~m})$ & 14.2 & 9.3 & 76.6 & 0.1 & 0.1 \\
\cline { 2 - 7 } & $1.7 \sim 1.9 \mathrm{~m})$ & 13.6 & 12.5 & 70.7 & 3.2 & 0.1 \\
\hline \multirow{3}{*}{ Site B } & $0.2 \sim 0.4(\mathrm{~m})$ & 23.5 & 7.0 & 34.8 & 34.7 & 0.1 \\
\cline { 2 - 7 } & $1.2 \sim 1.4(\mathrm{~m})$ & 25.7 & 6.7 & 39.2 & 28.4 & 0.1 \\
\cline { 2 - 7 } & $1.7 \sim 1.9(\mathrm{~m})$ & 33.1 & 10.8 & 37.4 & 18.1 & 0.1 \\
\hline \multirow{3}{*}{ Site C C } & $0.2 \sim 0.4 \mathrm{~m})$ & 62.5 & 10.2 & 27.4 & 0.1 & 0.1 \\
\cline { 2 - 7 } & $1.2 \sim 1.4(\mathrm{~m})$ & 65.1 & 18.6 & 16.4 & 0.1 & 0.1 \\
\cline { 2 - 7 } & $1.7 \sim 1.9(\mathrm{~m})$ & 49.5 & 31.4 & 19.1 & 0.1 & 0.1 \\
\hline
\end{tabular}

Table 2 Mineralogical composition of soils analyzed by XRD. (O, O, $\Delta$ and $\cdot$ represent the presence of large, medium, small and trace amount, respectively.

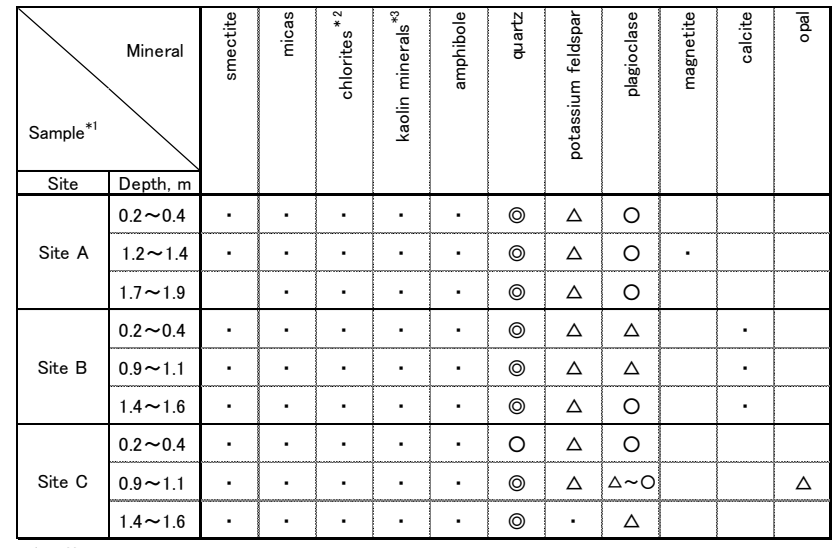

*1 Diffraction by untreated, ethylene glycol treated, hydrochloric acid treated and heat treated samples were measured for identification of clay minerals.

$* 2$ including vermiculite

$* 3$ including halloysite

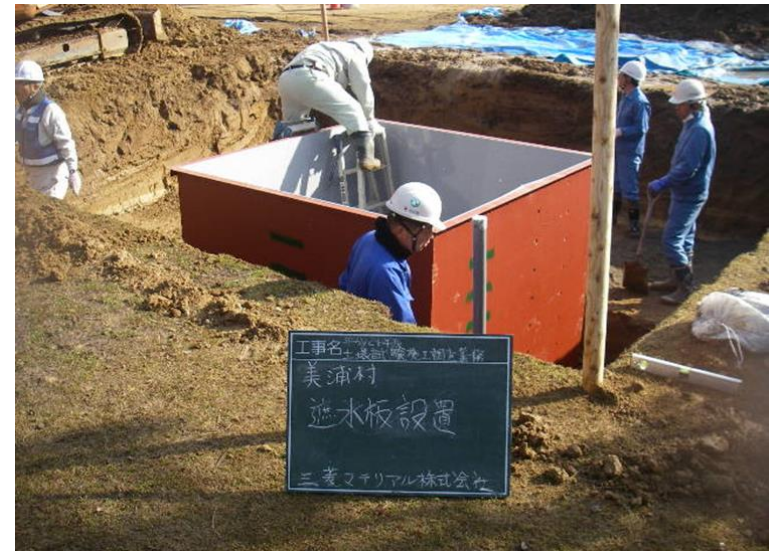

Fig. 1 A trench with an area of $6 \mathrm{~m} \times 6 \mathrm{~m}$ and a water impermeable steel frame installed at site $A$ in Miho, Ibaraki prefecture.

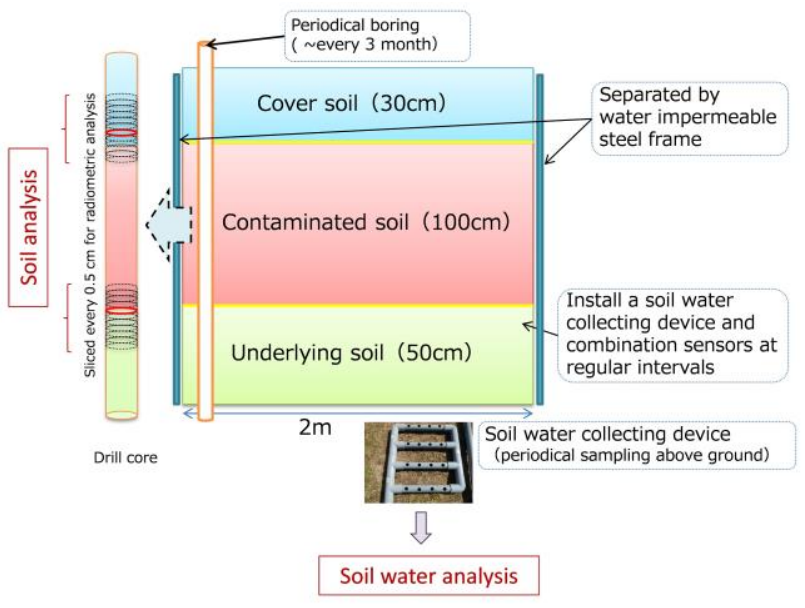

Fig. 2 Setup of the field experiments.

Water was sprinkled for about $8 \mathrm{~h}$ at a rate of $7 \sim 37 \mathrm{~mm} / \mathrm{h}$ almost every two weeks to attain an infiltration of $3200 \sim 3900$ $\mathrm{mm}$ during the experimental period. The infiltration is equivalent to $8 \sim 10$ years of natural infiltration by assuming that the amount of the water sprinkled was the same as that infiltrated. The annual precipitation is $1300 \mathrm{~mm}$, about $70 \%$ of which is estimated to evaporate and $30 \%$ infiltrated into the soil. Acidification of the sprinkled water simulating acid rains was not performed because the $\mathrm{pH}$ of the soil water was 6-8 and was considered reproducible by using neutral tap water. The daily average temperature was $-3{ }^{\circ} \mathrm{C}$ at lowest $(2014 / \mathrm{Feb} / 14)$ and 33 ${ }^{\circ} \mathrm{C}$ at highest (2013/Aug/10).

Vertical borings obtaining soil cores with a diameter of $20 \mathrm{~cm}$ were performed after around 20, 30, 130, 210, 360 days to investigate the radiocesium migration. The cores were sliced every $0.5 \mathrm{~cm}$ for radiometric analysis. The soil water was sampled monthly to determine radiocesium concentration, $\mathrm{pH}$, Eh, DO (dissolved oxygen concentration), SS (suspended solid concentration) and ammonia nitrogen concentration. Microbial activity was not analyzed because cesium does not help microbial metabolism and because no acidification of the soil water suggesting the microbial activities was observed. 
A demonstrative experiment on the migration of radiocesium from buried soil contaminated by the accident at Fukushima Daiichi Nuclear Power Station

\subsubsection{Site B in Misato city, Saitama Prefecture}

A $3-\mathrm{cm}$ thick contaminated surface soil was stripped from about $7200-\mathrm{m}^{2}$ area in the park using a sod cutter because the surface soil was clayey fine sand (Tables 1 and 2) and was covered with sod. Dose rate at $50 \mathrm{~cm}$ above the ground was typically $0.25 \mu \mathrm{Sv} / \mathrm{h}$ before the stripping and $0.11 \mu \mathrm{Sv} / \mathrm{h}$ afterwards. A trench with an area of $10 \mathrm{~m} \times 30 \mathrm{~m}$ and a depth of $1.0 \mathrm{~m}$ was dug. The contaminated soil with a volume of $210 \mathrm{~m}^{3}$ was buried in the trench at a depth range between 1.0 and $0.3 \mathrm{~m}$ and was covered with the clean local soils over $0.3 \mathrm{~m}$. A $2 \mathrm{~m} \times 2 \mathrm{~m}$ area in the buried area was separated as an investigation area by a water impermeable steel plate over a depth of $1.5 \mathrm{~m}$. This investigation area was dug down to a depth of $1.5 \mathrm{~m}$ in advance to install a soil water collecting device and the combination sensors at every $10 \mathrm{~cm}$ depths between 1.4 and $0.1 \mathrm{~m}$. The hydraulic conductivity had been between $1.2 \times 10^{-8}$ and $4.4 \times 10^{-8} \mathrm{~m} / \mathrm{s}$ in the buried area. The backfilling, borings, water sprinkling and soil water collection were performed in the same way as those at site A.

\subsubsection{Site $\mathbf{C}$ in Misato city, Saitama Prefecture}

A 3-cm thick contaminated surface soil was stripped from the whole park, about $350 \mathrm{~m}^{2}$ area. The surface soil was medium fine sand (Iwase sand) with no vegetation (Tables 1 and 2). Dose rate at $50 \mathrm{~cm}$ above the ground was typically $0.23 \mu \mathrm{Sv} / \mathrm{h}$ before the stripping and $0.15 \mu \mathrm{Sv} / \mathrm{h}$ afterwards. A trench with an area of $3 \mathrm{~m} \times 5 \mathrm{~m}$ and a depth of $1.0 \mathrm{~m}$ was dug at an edge of the park. The contaminated soil with a volume of $10.5 \mathrm{~m}^{3}$ was buried in the trench at a depth range between 1.0 and $0.3 \mathrm{~m}$ and was covered with the clean local soils over $0.3 \mathrm{~m}$. An investigation area was created in the same way as site $B$. The hydraulic conductivity had been between $2.9 \times 10^{-9}$ and $1.1 \times 10^{-8} \mathrm{~m} / \mathrm{s}$ in the buried area. The backfilling, borings, water sprinkling and soil water collection were performed in the same way as those at sites $\mathrm{A}$ and $\mathrm{B}$.

\subsection{Laboratory experiments}

\subsubsection{Column migration experiments}

Laboratory migration experiments of radiocesium from the contaminated soils were performed using soil columns. In an acrylic column with a diameter of $12 \mathrm{~cm}$ and a length of $30 \mathrm{~cm}$, the contaminated soil with a thickness of $12 \mathrm{~cm}$ was placed between a cover soil layer with a thickness of $8 \mathrm{~cm}$ and an underlying soil layer as shown in Fig. 3. The densities of the soils were the same as those in the field experiment as shown in Table 3. The lower end of the column was supported by a stainless steel wire mesh to allow suspended soil to flow through.

Twenty millimeters of deionized water was supplied from the top of the column every day to permeate $840 \mathrm{~mm}$ of water altogether. The down flow was selected for simulating the rainwater through aerated zones. The effluent was analyzed for Cs-137 concentration and turbidity without filtration because radiocesium was expected to migrate through the soil column mainly as adsorbed state onto soil particles.

In order to simulate more severe conditions under which underlying soil does not act as a barrier to the radiocesium migration, another column migration experiment was performed through a single contaminated soil layer. The soil column was 12 $\mathrm{cm}$ in diameter, $3 \mathrm{~cm}$ in thickness and $1.3 \mathrm{~g} / \mathrm{cm}^{3}$ in density. 140-mm water was permeated through the column at a rate of $20 \mathrm{~mm} / \mathrm{d}$.
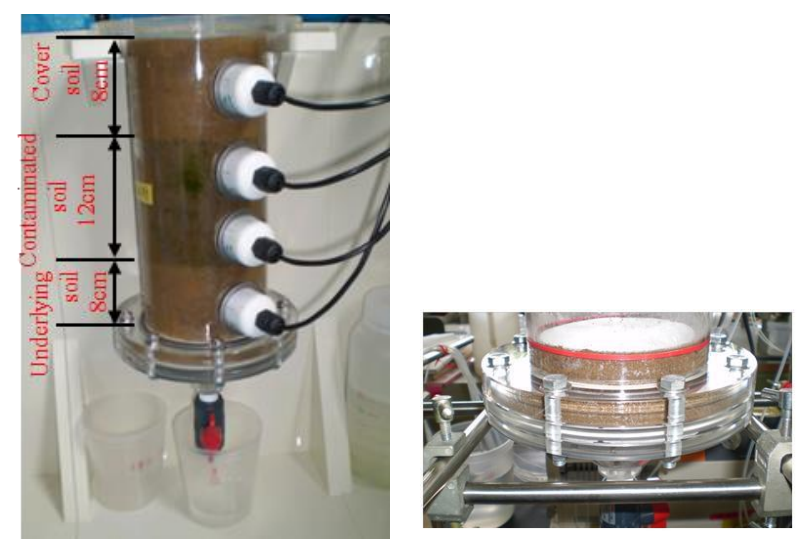

Fig. 3 Columns of the laboratory migration experiments. A column with three soil layers (left) and one with a single contaminated soil layer (right).

Table 3 Density and porosity of the soils determined using boring core samples taken after 10 days. The density of the contaminated soil at Site $B$ was somewhat lower than those at Sites $A$ and $C$. The density of the cover soil and the underlying soil are close because they were originally the same soil before the trench was dug.

\begin{tabular}{|l|c|c|c|}
\hline \multirow{2}{*}{} & \multicolumn{3}{|c|}{ Density $\left(\mathrm{g} / \mathrm{cm}^{3}\right) /$ Porosity (\%) } \\
\cline { 2 - 4 } & Site A & Site B & Site C \\
\hline Cover soil & $1.35 / 48.5$ & $1.44 / 46.1$ & $1.39 / 49.6$ \\
\hline $\begin{array}{l}\text { Contaminated } \\
\text { Soil }\end{array}$ & $1.40 / 45.9$ & $1.04 / 59.1$ & $1.53 / 42.3$ \\
\hline $\begin{array}{l}\text { Underlying } \\
\text { soil }\end{array}$ & $1.45 / 44.9$ & $1.41 / 46.9$ & $1.20 / 53.7$ \\
\hline
\end{tabular}

\subsubsection{Leaching experiments}

A sequential leaching test was performed in accordance with notification No.18 of the Ministry of the Environment [3]. Radiocesium dissolved in soil water was extracted with deionized water by shaking reciprocally for 6 hours at a liquid to solid ratio of $80 \mathrm{~mL} / 8 \mathrm{~g}$. After centrifugation, the cation exchanged radiocesium in the soil was extracted with $1 \mathrm{~mol} / \mathrm{L}$ $\mathrm{CH}_{3} \mathrm{COONH}_{4}$ solution by 18 -hour shaking.

Because the period of the sequential leaching test notified by Ministry of the Environment may be too short to obtain data to be used for assessing behavior of environmental radiocesium, long-term leaching tests were performed. Mixtures of soil and deionized water or $1 \mathrm{~mol} / \mathrm{L} \mathrm{CH}_{3} \mathrm{COONH}_{4}$ solution were manually shaken daily for 10 months. 


\subsubsection{Sorption experiments}

A core boring was performed at each site before digging the trench to obtain a soil sample from the depth between $30 \mathrm{~cm}$ and $180 \mathrm{~cm}$. Sorption distribution coefficients of Cs-137 on these soils were determined by using the standard method to determine the sorption distribution coefficient [4]. The soil was passed through a sieve with a mesh of $2 \mathrm{~mm}$. Three grams of the soil was mixed with $30 \mathrm{~mL}$ of deionized water in polyethylene bottles. After $24 \mathrm{~h}$, the mixture was added with a $1 \mathrm{~mL}$ volume of Cs-137 stock solution and was kept standing for $7 \mathrm{~d}$ being shaken manually once per day. The sorption run was performed ten-fold. The supernatant solution, filtrate through a $0.45 \mu \mathrm{m}$ filter and filtrate through a filter with a molecular weight cut-off of 10,000 was analyzed for Cs-137 radioactivity. The sorption distribution coefficient was determined by

$$
K d(\mathrm{~mL} / \mathrm{g})=\frac{C_{0}-C_{1}}{C_{1}} \times \frac{V_{a q}(\mathrm{~mL})}{W_{s}(\mathrm{~g})}
$$

$K d:$ sorption distribution coefficient $(\mathrm{mL} / \mathrm{g})$

$C_{0}$ : concentration of Cs-137 before sorption $(110 \mathrm{~Bq} / \mathrm{mL})$

$C_{1}$ : concentration of Cs-137 after sorption equilibrium $(\mathrm{Bq} / \mathrm{mL})$

$V_{a q}:$ volume of water $(\mathrm{mL})$

$W_{s}$ : mass of soil $(\mathrm{g})$

A blank test with deionized water and Cs-137 stock solution without the soil was also performed to confirm negligible adsorption of Cs-137 on the bottle walls. $\mathrm{CH}_{3} \mathrm{COONH}_{4}$ solutions, $\mathrm{NaCl}$ solutions and $\mathrm{KCl}$ solutions of $10^{-5} \sim 1 \mathrm{~mol} / \mathrm{L}$ concentrations were also used in place of deionized water in order to check the effect of the coexisting ions on the distribution coefficient. In this sorption experiments, effects of the acid rain on the sorption distribution coefficient were not considered.

\section{Results and discussion}

\subsection{Field experiments}

Fig. 4 shows the concentration of Cs-137 determined for the vertical boring core intersecting the interface between the cover soil and the contaminated soil and that between the contaminated soil and the underlying soil. The concentration of Cs-137 is $1000 \sim 3000 \mathrm{~Bq} / \mathrm{kg}$ in the contaminated soil and less than the detection limit $(11 \sim 13 \mathrm{~Bq} / \mathrm{kg})$ in the cover soil and in the underlying soil for the sites $\mathrm{A}$ and $\mathrm{C}$. At sites $\mathrm{A}$ and $\mathrm{C}$, Cs-137 had been retained within $3 \mathrm{~cm}$ from the surface before the demonstrative experiments and was entirely removed by stripping the 3-cm thick surface soil. At site B on the other hand, small amounts of Cs-137 had existed at the depth range of 3 $10 \mathrm{~cm}$ before the demonstrative experiments, was not removed by the 3-cm stripping and was accordingly transferred to the soil used as underlying soil and as cover soil. This is the reason why the concentration of Cs-137 in the cover soil and in the underlying soil of $10 \sim 40 \mathrm{~Bq} / \mathrm{kg}$ is observed at site $\mathrm{B}$.
The concentration of Cs-137 changes not sharply but rather gradually at the interfaces over $5 \mathrm{~cm}$. The concentration distribution was due not to migration of Cs-137 because that was observed for the boring core just after burying before sprinkling water. The concentration distribution was due to the coexistence of the contaminated soil and the cover soil or the underlying soil in 5-mm thick segments. The depth ranges where such coexistence was observed were shown as coexisting range in Fig. 4. The coexistence would occur during the burying and ramming processes. Increase in the concentration of Cs-137 in the cover soil and in the underlying soil was not observed beyond the coexisting ranges as shown in Fig. 5.

The results of the analyses of the water collected by the soil water collecting device are shown in Table 4. Cs-137 was not detected in all water samples. Lower Eh and higher ammonia nitrogen concentration were observed at site $\mathrm{B}$ than those at other sites. Those would have something to do with the higher groundwater level at site $\mathrm{B}$; the groundwater level was deeper than $3 \mathrm{~m}$ at site $\mathrm{A},>3 \sim 0.5 \mathrm{~m}$ at site $\mathrm{B}$ and $2.0 \sim 1.0 \mathrm{~m}$ at site $\mathrm{C}$. No influence of the water sprinkling was observed on the groundwater level.

No indication of the migration of Cs-137 was observed from the field experiments.

Table 4 Results of soil water analyses.

\begin{tabular}{|l|c|c|c|}
\hline & Site A & Site B & Site C \\
\hline Cs-137 & ND & ND & ND \\
\hline $\mathrm{pH}$ & $6 \sim 8$ & $6 \sim 8$ & $6 \sim 8$ \\
\hline Eh (mV vs.NHE) & $\begin{array}{c}+281 \\
+464\end{array}$ & $-60 \sim+124$ & $\begin{array}{c}+350 \\
\sim+481\end{array}$ \\
\hline $\begin{array}{l}\text { Dissolved oxygen } \\
\text { (mg/L) }\end{array}$ & $1.23 \sim 3.86$ & $0.99 \sim 3.53$ & $1.65 \sim 3.65$ \\
\hline $\begin{array}{l}\text { Suspended solid } \\
\text { (mg/L) }\end{array}$ & $5 \sim 261$ & $8 \sim 271$ & $5 \sim 657$ \\
\hline $\begin{array}{l}\text { Ammonia } \\
\text { nitrogen (mg/L) }\end{array}$ & $3<$ & $0.5 \sim 3<$ & $1 \sim 2$ \\
\hline $\begin{array}{l}\text { Groundwater } \\
\text { level (GL- m) }\end{array}$ & $<0.1 \sim 0.7$ & $1.0 \sim 11$ & $0.2 \sim 0.5$ \\
\hline
\end{tabular}

\subsection{Laboratory experiments}

\subsubsection{Column migration experiments}

The concentrations of Cs-137 in the effluents of the 2 types of column migration experiments using the soil sampled from 3 sites were under the detection limit $\left(<2 \mathrm{~Bq} / \mathrm{cm}^{3}\right)$. The result suggests that soil particles adsorbing Cs-137 were hardly suspended in water or were re-captured in soil lumps after being suspended. Results of the radiometric analysis of the soil columns after the migration experiments did not indicate any migration of Cs-137 upward and downward.

\subsubsection{Leaching experiments}

In the sequential leaching tests using deionized water or 1 $\mathrm{mol} / \mathrm{L} \mathrm{CH}_{3} \mathrm{COONH}_{4}$ solution, radiocesium was not detected 
A demonstrative experiment on the migration of radiocesium from buried soil contaminated by the accident at Fukushima Daiichi Nuclear Power Station
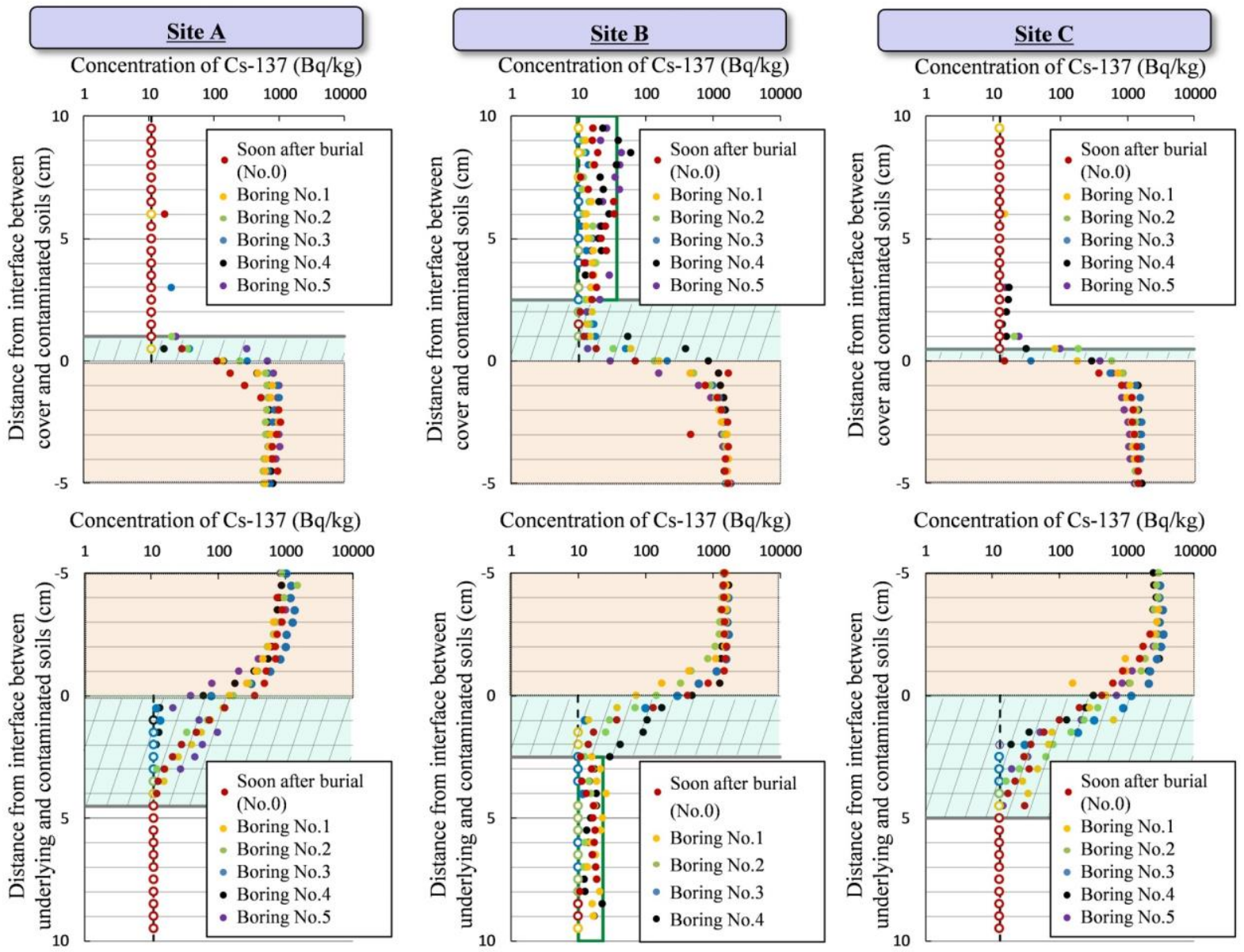

:Cover/Underlying soil

:Coexisting range

:Contaminated soil

Fig. 4 Concentration of Cs-137 determined by radiometric analysis of boring cores. The detection limits were shown by open marks in the case that the concentration was under the detection limit.
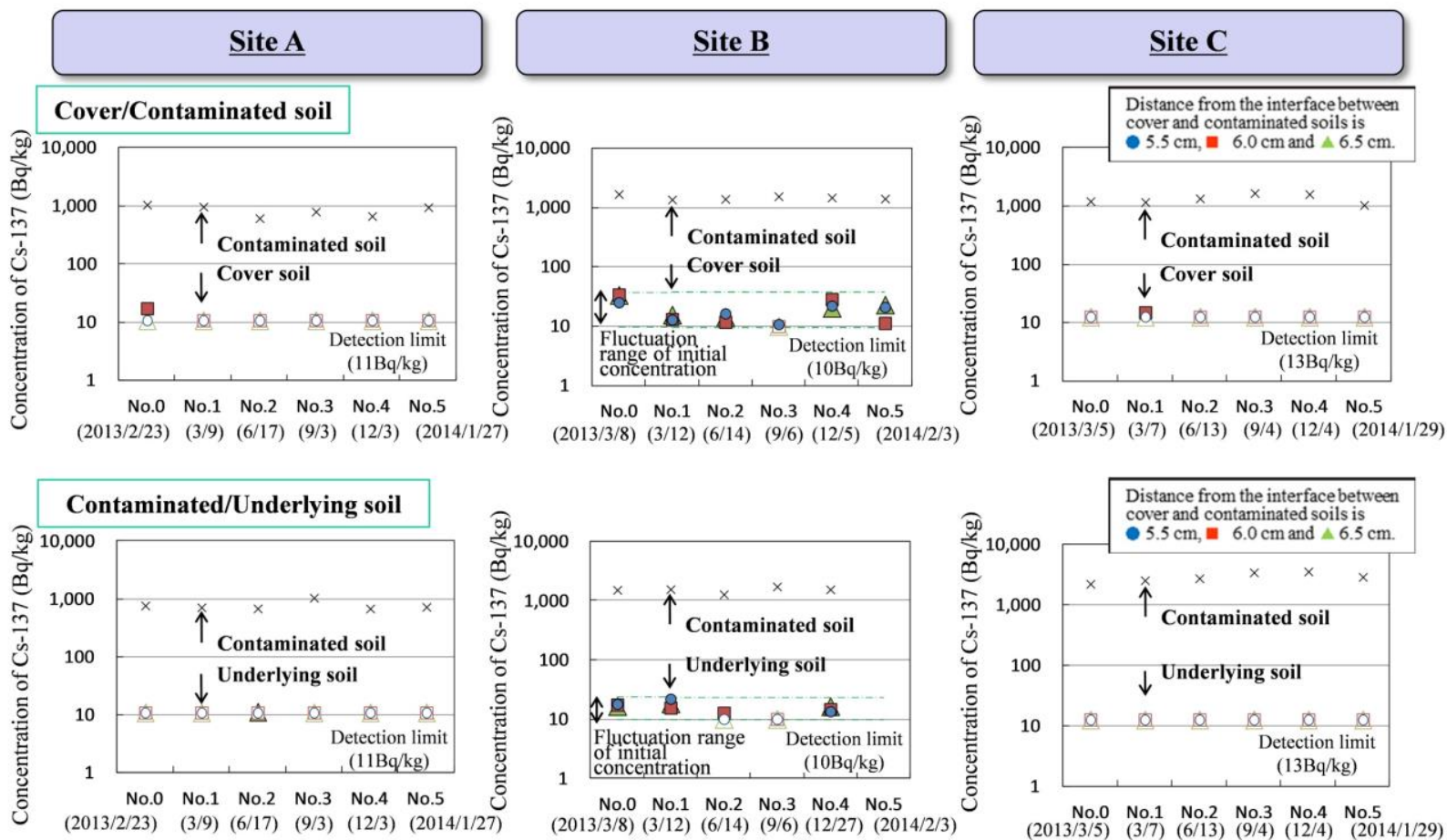

Fig. 5 Change of the concentration of Cs-137 with time in the contaminated soil and in the cover and the underlying soils. The detection limits were shown by open marks in the case that the concentration was under the detection limit. 
(detection limit: $10 \sim 15 \mathrm{~Bq} / \mathrm{L}$ ) in any of the leachates. The long-term leaching tests also showed no radiocesium, concentration in all the leachates were under the detection limit (1 $\sim 2 \mathrm{~Bq} / \mathrm{L}$ ). The results suggest that radiocesium in the soils hardly dissolves in permeated rainwater or in groundwater.

\subsubsection{Sorption experiments}

The sorption distribution coefficients obtained in the sorption experiments were shown in Fig. 6 for site A. The ammonium concentration dependences of the sorption distribution coefficients on the soils from sites $\mathrm{B}$ and $\mathrm{C}$ were similar to that for site A. The sorption distribution coefficient is as high as $10^{3}$ to $10^{4} \mathrm{~mL} / \mathrm{g}$ under the cation concentrations less than $10^{-3} \mathrm{~mol} / \mathrm{L}$ anticipated in actual environments. The range of sorption distribution coefficients was the same as those for the sites $\mathrm{B}$ and C. The concentrations of $\mathrm{Na}^{+}$and $\mathrm{K}^{+}$in river water are typically $2.9 \times 10^{-4}$ and $3.0 \times 10^{-5} \mathrm{~mol} / \mathrm{L}$, respectively [5] and are lower than the $10^{-3} \mathrm{~mol} / \mathrm{L}$. The concentration of ammonia nitrogen in the soil water at the sites was $11 \mathrm{mg} / \mathrm{L}$ or $7.9 \times 10^{-4} \mathrm{~mol} / \mathrm{L}$ at highest as shown in Table 4, which is also lower than the $10^{-3} \mathrm{~mol} / \mathrm{L}$. The results ensure that radiocesium is adsorbed on surrounding soil particles and does not migrate even if leached from the contaminated soils into soil water. The sorption distribution coefficient of radiocesium is discussed in relation to the clay content of the soil in some cases and is found less correlated to the clay contents in other cases [6]. Further study is necessary for establishing the correlation.

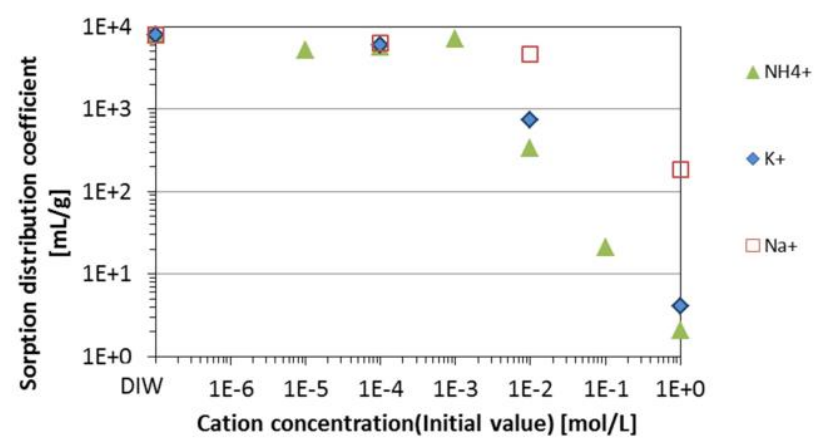

Fig. 6 Sorption distribution coefficient of Cs on soil obtained from the site $A$ as a function of the concentration of cations in aqueous phase.

\section{Extrapolation beyond the experimental period by model simulation}

Although migration of radiocesium through the soil layer was not detected in the field experiments, it might occur over longer periods. A series of calculations were performed simulating vertical migration of Cs-137 over 100 years.

A computer code, GoldSim (GoldSim Technology Group LLC, USA), capable of mass transport analysis with decay of radionuclides, was used. A one-dimensional system that consists of cover soil, contaminated soil and underlying soil was considered. The basic mass balance equation is as follows:

$$
\begin{aligned}
& \frac{\partial}{\partial t} R t_{i} \cdot C_{g w, i}(x, t)=D_{x} \cdot \frac{\partial^{2} C_{g w, i}(x, t)}{\partial x^{2}}-U_{g w} \cdot \frac{\partial C_{g w, i}(x, t)}{\partial x} \\
& -R t_{i} \cdot \lambda_{i} \cdot C_{g w, i}(x, t)+R t_{i-1} \cdot \lambda_{i-1} \cdot C_{g w, i-1}(x, t)
\end{aligned}
$$

where $R t_{\mathrm{i}}$ is the retardation factor of Cs migration through the soil [-], $C_{g v, i}(x, t)$ the concentration of Cs-137 [Bq $\left./ \mathrm{m}^{3}\right]$ at a depth $x[\mathrm{~m}]$ and at time $t[\mathrm{y}], D_{x}$ the longitudinal dispersion coefficient $\left[\mathrm{m}^{2} / \mathrm{y}\right], U_{g w}$ the permeation rate $\left[\mathrm{m}^{3} / \mathrm{m}^{2} / \mathrm{y}\right], \lambda_{i}$ the decay constant of Cs-137 [1/y]. The $R t_{i}$ and $D_{x}$ were given as:

$$
\begin{aligned}
& R t_{i}=1+\frac{1-\varepsilon_{s}}{\varepsilon_{s}} \cdot \rho_{s} \cdot K d_{s, i} \quad \text { and } \\
& D_{x}=D_{l} \cdot\left|U_{g w}\right|+D_{m}
\end{aligned}
$$

where $\varepsilon_{s}$ is the porosity of the soil [-], $\rho_{s}$ the density of the soil $\left[\mathrm{g} / \mathrm{cm}^{3}\right], K d_{S, i}$ the sorption distribution coefficient of Cs onto soil $[\mathrm{mL} / \mathrm{g}], D_{l}$ the longitudinal dispersion length $[\mathrm{m}]$ and $D_{m}$ the diffusion coefficient $\left[\mathrm{m}^{2} / \mathrm{y}\right]$.

Conditions of the calculations are shown in Table 5. The sorption distribution coefficient was assumed to be $1000 \mathrm{~mL} / \mathrm{g}$, which was the lowest value obtained in the laboratory sorption experiment using the soils obtained from the sites and deionized water. The sorption distribution coefficients obtained in the presence of cations were not used because they were unrealistically low. The infiltration rate of rainwater in Japan [5] was used as the infiltration rate. The porosity and the density were taken from our measurements. The diffusion coefficient is the molecular diffusion coefficient of $\mathrm{Cs}^{+}$in water. Although irreversible sorption of Cs-137 on soils may occurs in the fields, only reversible sorption was considered in the simulation in order not to underestimate the Cs-137 migration.

Table 5 Conditions of the calculation. Values in parenthesis are the ones obtained in the experiments.

\begin{tabular}{|c|c|}
\hline Parameter & Value \\
\hline $\begin{array}{c}\text { Infiltration rate into soils } \\
\left(\mathrm{m}^{3} / \mathrm{m}^{2} / \mathrm{y}\right)\end{array}$ & $0.4[5]$ \\
\hline $\begin{array}{c}\text { Sorption distribution coefficient } \\
\text { of Cs }(\mathrm{mL} / \mathrm{g})\end{array}$ & $\begin{array}{c}1,000 \\
(5,400 \sim 8,200)\end{array}$ \\
\hline Porosity (-) & $0.5(0.5)$ \\
\hline Density $\left(\mathrm{kg} / \mathrm{m}^{3}\right)$ & $1,350(1,350)$ \\
\hline Diffusion coefficient $\left(\mathrm{m}^{2} / \mathrm{s}\right)$ & $2 \times 10^{-9}[7]$ \\
\hline Dispersivity $(\mathrm{m})$ & $0.01[7]$ \\
\hline
\end{tabular}

The results of the calculations were shown in Fig. 7. Only a small amount of Cs-137 was predicted to migrate downward and upward from the initial position via water permeation and diffusion. At $5 \mathrm{~cm}$ deeper from the interface between the contaminated soil and the underlying soil, for example, the concentration of Cs-137 was evaluated to be as high as $10 \%$ of 
A demonstrative experiment on the migration of radiocesium from buried soil contaminated by the accident at Fukushima Daiichi Nuclear Power Station

the initial concentration in the contaminated soil after $30 \sim 50$ years. At the same time, the concentration of Cs-137 was evaluated to be $1 \%$ of the initial concentration in the contaminated soil at $10 \mathrm{~cm}$ deeper than the interface and $0.001 \%$ at $20 \mathrm{~cm}$. The concentration was evaluated to be $4 \%$ at $5 \mathrm{~cm}, 2 \%$ at $10 \mathrm{~cm}$ and $0.1 \%$ at $20 \mathrm{~cm}$ after 100 years. Almost all the Cs-137 is expected to decay out in the contaminated soil layer.

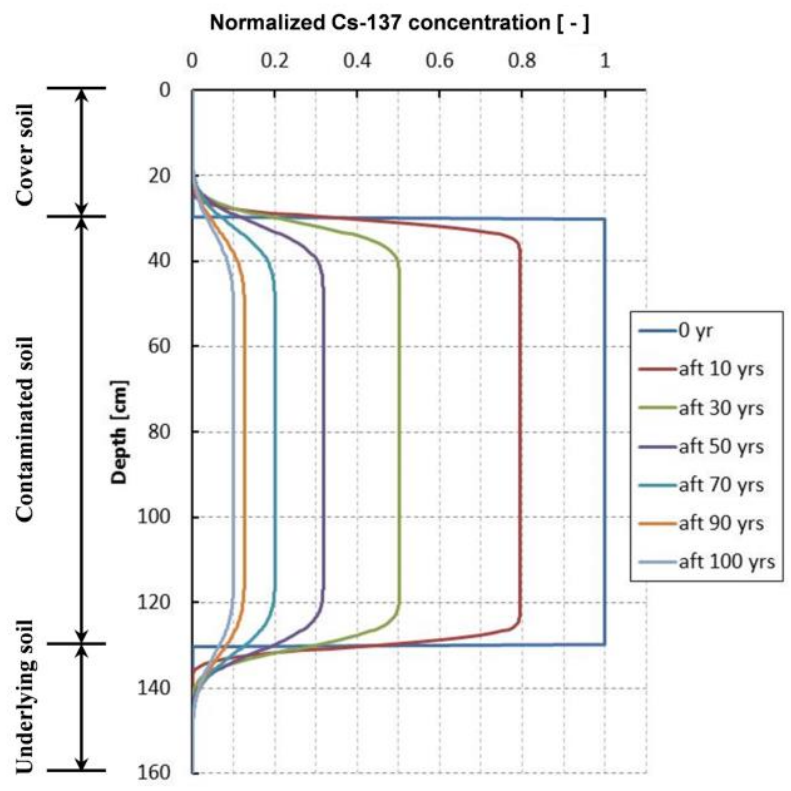

Fig. 7 Results of the model simulation of migration of Cs-137 over 100 years.

\section{Conclusion}

Soils contaminated by the accident at Fukushima Daiichi Nuclear Power Station were buried and covered with clean local soils in a public park in Miho, Ibaraki prefecture and in two public parks in Misato, Saitama prefecture in order to examine migration of radiocesium over a year. Migration of radiocesium was not detected from the radiometric analysis of the boring cores and the soil water samples.

Laboratory column and sorption experiments revealed that the radiocesium hardly leaches out of the soil and even if they leach out from the contaminated soil, radiocesium is sorbed on surrounding soils and hardly migrates through the soil layer.

Simulation of the Cs-137 migration for 100 years by an advection-diffusion model showed that Cs-137 migrates slightly and decays out in the contaminated soil.

\section{Acknowledgement}

Mr. S. Sugano of Miho village office, Mr. S. Akimoto, Mr. J. Fujimaru, Mr. Y. Saga and Mr. W. Nakamoto of Misato municipal office are acknowledged for their support to the field experiments. Mr. R. Tatsuta and Mr. J. Kurosaka of Ministry of the Environment are acknowledged for their contribution as secretaries. Mr. M. Mukai and Dr. T. Tanaka of JAEA and Mr. H.
Kato and Ms. S. Shimoda of Mitsubishi Materials Corporation and Mr. N. Kiyanagi and M. Saga of Mitsubishi Materials Techno Corporation are acknowledged for their technical contribution. Dr. Logan Barr of Japan Atomic Energy Agency is acknowledged for linguistic amendment.

\section{References}

[1] Kamiyama, H., Yamamoto, T., Shimooka, K., Takebe, S., Ogawa, H., Tanaka, T., Mukai, M., Komiya, T., Li, Shu., Wang, Z., Guo, Z., Li, Z., Zhao, Y. and Li, She.: Field Test of Radionuclide Migration - Cooperation Research between JAERI and CIRP -. JAERI Research 94-009 (1994). (in Japanese)

[2] Sakamoto, Y., Nakamura, H., Killey, R. W., Champ, D. R.: Migration Behavior of $\mathrm{Sr}-90$ and $\mathrm{Cs}-137$ in a sand aquifer: Results of a 30-years experiment. 10 $0^{\text {th }}$ Pacific Basin Nuclear Conf., vol.2, Kobe, Japan, October 23-27, 1996, pp.1343-1350 (1996).

[3] Ministry of the Environment: Notification of the measurement method of leaching of soils. Notification No. 18 of the Ministry of the Environment (2003). (in Japanese)

[4] Atomic Energy Society of Japan: Technical Report of "Measurement Method of the Distribution Coefficient on the Sorption Process - Basic Procedure of Batch Method relevant to the Barrier Materials used for the Shallow Land Disposal:2002 and Basic Procedure of the Method Relevant to the Barrier Materials used for the Deep Geological Disposal: 2006”. Committee for Standardization in Atomic Energy Society of Japan, AESJ-SC-TR001:2006 (2006). (in Japanese)

[5] Editorial board of revised handbook of groundwater: Revised handbook of groundwater. Construction Industry Research Committee (1998). (in Japanese)

[6] Office of Radiation and Indoor Air, EPA: Understanding variation in partition coefficient $\mathrm{K}_{\mathrm{d}}$, values. EPA 402-R-99-004B (1999).

[7] Japanese Association of Groundwater Hydrology: Simulation of groundwater flow and solute transport. Gihodo Shuppan (2010). (in Japanese) 
